Full-text Available Online at www.bioline.org.br/ja
J. Appl. Sci. Environ. Mgt. September, 2006

Vol. 10 (3) 103 - 107

\title{
Antibiotic Sensitivity Pattern of Urinary Tract Pathogens in Port - Harcourt, Nigeria
}

\author{
*11UWAEZUOKE, J C; ${ }^{2}$ OGBULIE, J N \\ ${ }^{1}$ Department of Microbiology, Imo State University P.M.B. 2000, Owerri, Nigeria \\ ${ }^{2}$ Department of Microbiology, Federal University of Technology, Owerri, Nigeria
}

\begin{abstract}
The prevalence and sensitivity pattern of urinary pathogens from 1240 patients in Port-harcourt, Nigeria was investigated. The predominant pathogens cultured was $E$. coli which accounted for $76.6 \%$ of the infections. Klebsiella spp was responsible for $8.1 \%$ of cases while the rest were accounted for by Proteus spp (4.8\%), coagulase-negative staphylococci (3.2\%), Pseudomonas spp (2.4\%), Enterobacter spp. (2.4\%), Staphylococcus aureus $(1.6 \%)$ and Citrobacter species $(0.8 \%)$. The majority of the isolates were resistant to tetracycline $(75.8 \%)$, ampicillin $(71.0 \%)$ and cotrimoxazole $(65.3 \%)$ but exhibited good sensitivity to nitrofurantoin $(88.7 \%)$, gentamicin $(85.5 \%)$ and nalidixic acid $(76.6 \%)$. It is recommended that a periodic reassessment of the sensitivity pattern of urinary pathogens be carried out to serve as a guide for antibiotic therapy of UTIs in a particular environment since these organisms exhibited resistance to first-line drugs used for UTI infections. @JASEM
\end{abstract}

Despite impressive advances in the understanding of the pathogenesis, diagnosis and treatment of urinary tract infections (UTIs), these infections still remain a major clinical problem. Many consultations in general practice are because of urinary infections (Sleigh and Timbury, 1986). UTIs, although, less frequently a cause of renal failure, do produce considerable morbidity particularly among young females. UTIs are also an important complication of pregnancy and when associated with structural or neurological lesions of the urinary tract at any age, often lead to severe incapacity and death (Stamey and Pfau, 1970; Kunin 1987; Cunningham et al., 1973; Whalley et al., 1975). The use of antibiotics is clearly widespread in our modern society. Antimicrobial drugs such as tetracycline, sulphonamides and ampicillin which are often used in the treatment of disorders such as gastrointestinal, wound and minor respiratory infections are also the most commonly used drugs in the treatment of urinary infections. Bacteria generally implicated in UTI commonly originate in the intestine (Senewiratne et al, 1973; Cattel et al, 1974; Sleigh and Timbury, 1986). The extensive use of these drugs, often for infections outside the urinary tract, would alter the antibiotic susceptibility pattern of intestinal bacteria which mostly constitute the bacteria that colonize the urinary tract (Senewiratne et al, 1973). Also the rate at which resistance arises among microbial populations is often dictated by the extent of use of particular agents in a given environment (Kabins and Cohen, 1966; Watanabe, 1966; McGowan, 1983; Lambert, 1988; Kunin et al, 1990; Jacoby and Archer, 1991). To effectively treat and control infections such as the UTIs in a particular environment, a good knowledge of the antibiotic sensitivity pattern of the causative agents in that environment is therefore of ultimate importance.

There is no organized surveillance of drug resistance among common UTI pathogens in Nigeria, however, few reports available from Ibadan (Adeyemo et al, 1994) and Benin (Obaseiki - Ebor, 1988) show that resistance to commonly prescribed antibiotics for UTI exists. The aim of this study was to identify the prevalent UTI pathogens in individuals attending private diagnostic laboratories in the industrial city of Port-Harcourt, Nigeria and investigate their sensitivity pattern to commonly used antibiotics in the environment.

\section{MATERIALS AND METHODS}

The study was performed on 1240 patients attending private diagnostic laboratories in Port-Harcourt metropolis, between June $1^{\text {st }}, 1995$ and May $30^{\text {th }}$ 1996. The laboratories were Auspharm Medical Laboratory Diagnostic Services and Rimot Diagnostic Laboratory, all in Port Harcourt. Only patients who have clinical symptoms of UTI and positive urine culture $\left(\geq 10^{5}\right.$ organisms $/ \mathrm{ml}$ ) were studied. The mid-stream urine specimens were obtained by clean - catch method (Kunin, 1987). The samples were collected in sterile universal containers and cultured within 30 minutes of collection. The samples were plated out on MacConkey and blood agar media and incubated aerobically overnight at 37 ${ }^{0} \mathrm{C}$. Samples that showed pure growth of isolate in a count of $\geq 10^{5}$ colony-forming units (CFU) per $\mathrm{ml}$ of urine after overnight incubation were considered to

*Corresponding author: E-mail: uwaezuoke_uwaezuoke@yahoo.com 
indicate significant bacteriuria (Sleigh and Timbury, 1986; Gerald et al, 1990). Identification of organisms was by standard methods while antimicrobial sensitivity tests were carried out by disc diffusion technique (Rapheal, et al, 1983) using isosensitest agar (Oxoid, Basingstoke, U.K.). E coli strains susceptible to all the antibiotics tested were used as controls.

\section{RESULT}

Bacterial organisms were isolated from the urine of 1240 patients during the study. There were 1100 $(88.7 \%)$ females and $140(11.3 \%)$ males. The male: female ratio was 1:7.9. The age range of the females was 16-32 years and that of the males was 18-30 years. The symptoms of the subjects included frequency, dysuria, suprapubic and loin pains. The urinalysis of the patients is as shown in table 1. A total of 1240 isolates were obtained from the patients. The biochemical properties of the isolates are shown in Table 2. The predominant organism was E. coli which was responsible for $76.6 \%$ of the infection (Table 3). Klebsiella was responsible for $8.1 \%$ of the infections while the rest were accounted for by Proteus spp. (4.8\%), coagulase negative staphylococci (3.2\%), Pseudomonas spp. (2.4\%), Enterobacter spp. (2.4\%), Staphylococcus aureus $(1.6 \%)$ and Citrobacter spp (0.8\%).

Table 1: Mid-stream urinalysis of patients with acute urinary tract infections (UTIs)

\begin{tabular}{|c|c|}
\hline \multicolumn{2}{|c|}{$\begin{array}{l}\text { ParametersPatients with acute examined } \\
\text { UTIs. } \mathrm{n}=1240\end{array}$} \\
\hline \multicolumn{2}{|c|}{ WBC/HPF: } \\
\hline $0-4$ & 120 \\
\hline$\geq 5$ & 1120 \\
\hline \multicolumn{2}{|c|}{ RBC/HPF 0} \\
\hline \multicolumn{2}{|c|}{ PROTEIN: } \\
\hline \multicolumn{2}{|c|}{ Negative 1180} \\
\hline Trace & 40 \\
\hline$\geq+$ & 20 \\
\hline \multicolumn{2}{|c|}{ GLUCOSE: } \\
\hline Negative & 1240 \\
\hline Trace & 0 \\
\hline$\geq+$ & 0 \\
\hline \multicolumn{2}{|l|}{ CASTS: } \\
\hline 0 & 1220 \\
\hline$\geq 1 / \mathrm{HPF}$ & 20 \\
\hline
\end{tabular}

The sensitivity of the isolates to seven antimicrobial agents is shown in Table 3. The three commonest isolates exhibited sensitivity of less than $37 \%$ to ampicillin, tetracycline and cotrimoxazole. Most of the isolates were susceptible to nitrofurantoin, gentamicin, streptomycin and nalidixic acid. Nitrofurantoin and gentamicin were effective against over $80 \%$ of the strains of E. coli, Klebsiella spp and
Proteus spp while nalidixic acid and streptomicin were effective against over $60 \%$ of these organisms, (Table 3). The percentage resistance of all the isolates (when considered together) to the different antimicrobial agents is shown in Figure 1. The highest resistance was recorded with tetracycline while the lowest resistance was with nitrofurantoin 


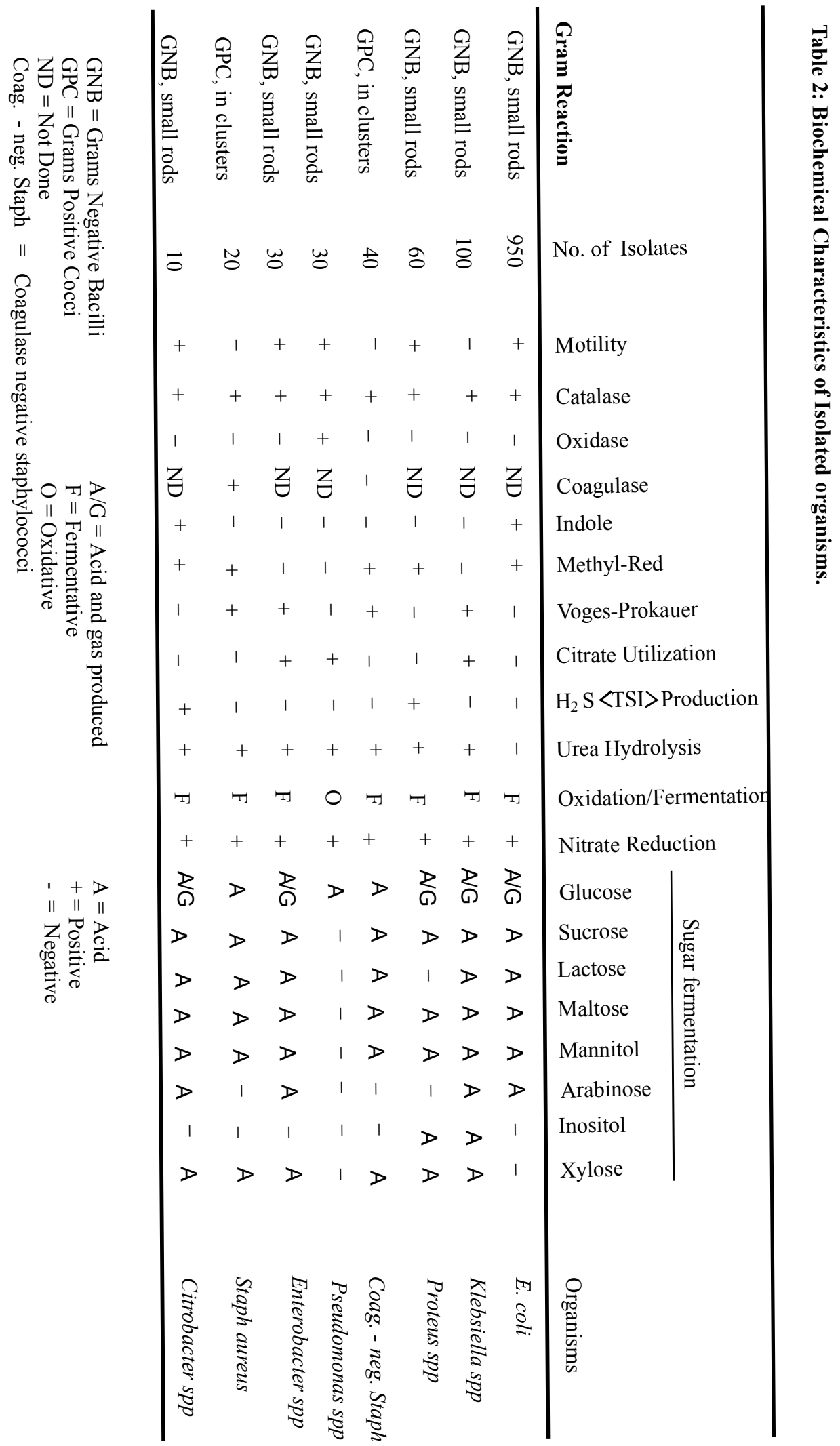




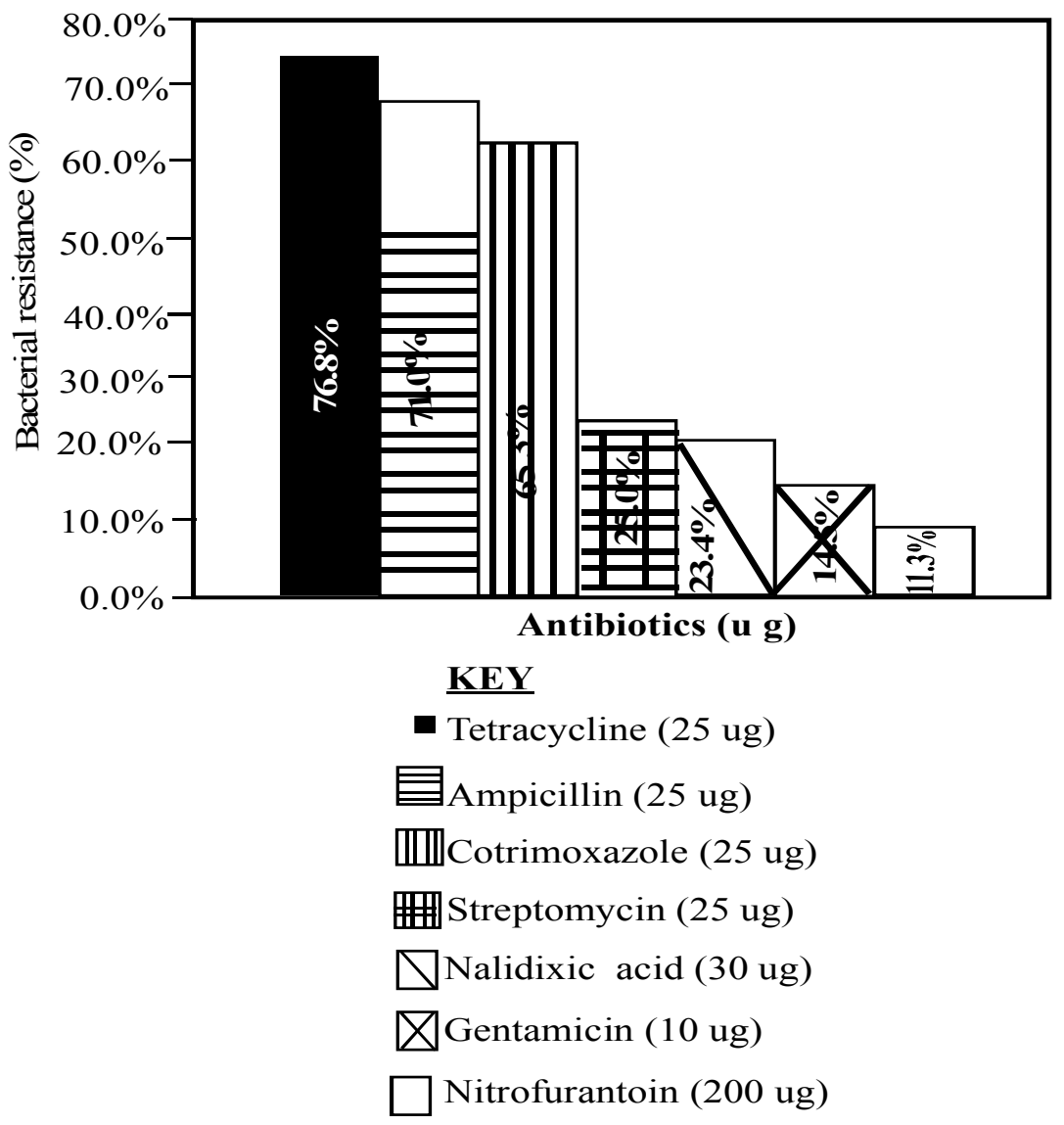

Fig. 1 Percentage resistance of bacterial isolate (causing UTIs) to individual antibiotics

\section{DISCUSSION}

The pattern of pathogens causing UTI in Port Harcourt and their antibitic sensitivity pattern is reported. E. coli was the most frequent species isolated in this study. This accord with the findings of other workers (Stamey and Pfau, 1970; Senewiratne et al, 1973; Pfau and Sacks, 1981; Asseffa and Yohannes, 1996). The percentage sensitivity of the most isolated organisms ( E. coli, Klebsiella spp, and Proteus spp) to the commonly used antibiotics for UTI, namely ampicillin, cotrimoxazole and tetracycline was low (Table 3 ). High incidence of resistance to these drugs has been reported by other workers (Senewiratne et al., 1973; Akinkugbe et al., 1988;Obaseiki-Ebor, 1988; Aseffa and Yohannes, 1996). In this study, the percentage resistance by $E$. coli to ampicillin, cotrimozaxole and tetracycline are $69.5 \%, 64.2 \%$ and $74.7 \%$ respectively. A high percentage resistance by $E$. coli to these antibiotics have been reported by other workers (Senewiratne, et al., 1973; Obaseiki-Ebor, 1988; Adeyemo et al, 1994; Aseffa and Yohannes, 1996). Obaseiki-Ebor (1988) in his study in Benin (Nigeria) of 40 isolates of E. coli from UTI, found that $80 \%$ of the $E$. coli isolates were resistant to cotrimoxazole while Adeyemo et al (1994) found a $100 \%$ resistance to both cotrimoxazole and ampicillin by the E. coli isolates in their study in Ibadan (Nigeria).
In this study, a high sensitivity rate to nitrofurantoin (90.5\%), Nalidixic acid (82.1\%) and gentamacin (81.1\%) was recorded for $E$. coli, the most predominant isolate. Other workers have also recorded a high $E$. coli sensitivity rate to these drugs (Senewiratne et al, 1973; Adeyemo et $a l, 1994)$. The high incidence of resistance to tetracycline, ampicillin and cotrimoxazole (Fig. 1) in the present study may be attributed to the easy access to and indiscriminate use of these drugs in the Port Harcourt metropolis. These drugs are commonly used for infections outside the urinary tract (Senewirante et al, 1973) and with this pattern of resistance, it is recommended that cotrimoxazole, tetracycline and ampicillin should not be used as first line agents in the blind treatment of UTIs in the Port Harcourt metropolis. This is more so, as infections caused by resistant pathogens have with them, higher rates of morbidity and mortality than do infections caused by susceptible pathogens (Holmberg et al, 1987). Since a very high percentage of isolates in this study were sensitive to nitrofurantoin, this drug would be a better choice for UTI therapy; it could be administered while waiting the culture result.

The appropriate use of antibiotics however with the knowledge of the sensitivity pattern would help reduce the rate of morbidity as well as limit the increasing rate of drug resistance among bacteria. It is the recommendation of this 
study that constant evaluation of the antibiotic sensitivity pattern of UTI pathogens for commonly used antimicrobial agents in a particular environment be carried out

\section{REFERENCES}

Adeyemo, A A; Gbadegesin R A; Onyemenem, T N; Ekweozor, C C (1994). Urinary tract pathogens and antimicrobial sensitivity pattern in children in Ibadan, Nigeria. Annals of Tropical Paediatrics 14: $271-274$.

Akinkugbe, F M; Akinnwolere O A; Onyewole, A I M (1988), A symptomatic bacteriuria and other urinary abnormalities in children in Ibadan. Nigerian Journal of Peadriatic. 15: 11-18.

Aseffa, A and Yohannes G (1996). Antibiotic sensitivity pattern of prevalent bacterial pathogens in Gonder, Ethiopia. East African Medical Journal. 73: 67-71.

Cattell, W R; McSherry, M A; NorthEast, A; Powell, E; Brooks, H.J. L and O' Grady, F. (1974) Periurethral enterobacterial carriage in pathogenesis of recurrent urinary infection. British Medical Journal. 4: 248252.

Cunningham, F G; Morris, G B; Mickal, A (1973). Acute pyelonephritis of pregnancy: a clinical review. Obstetrics and Gynecology, 42: 112-117.

Gerald L M; Douglas, R G; Benette, J E (1990). Principles and Practice of Infectious Diseases. $3^{\text {rd }}$ edition. pp. 582-590. Churchill Livingstone, New York.

Holmberg, S D; Solomon, S L; Blake, P A (1987). Health and economic impacts of antimicrobial resistance. Review of Infectious Diseases. 9: 1065-1078.

Jacoby, G A and Archer, G L (1991). New mechanisms of bacterial resistance to antimicrobial agents. New England Journal of Medicine, 324: 601-612.

Kabins, A E and Cohen, S (1966). Resistance factor in Enterobacteriaceae. New England Journal of Medicine, 275: 248-252.

Kunin, C M (1987). Detection, Prevention and Management of Urinary Tract Infections. pp. vii, 1-93, Lea and Febiger, Philadelphia.
Kunin, C M; Johansen, K S; Worning, A M; Daschner, F D (1990). Report of a symposium on use and abuse of antibiotics worldwide. Review of Infectious Diseases. 12: $12-19$.

Lambert, H P (1988). Clinical impact on drug resistance. Journal of Hospital Infection, II (Suppl. A): 135-141.

McGowan, J E Jr (1983). Antimicrobial resistance in hospital organisms and its relation to antibiotic use. Review of Infectious Diseases. 5: 1033-1048.

Obaseike-Ebor, E E Trimethoprim/Sulphamethoxazole reistance in Escherichia coli and Klebsiella spp. urinary isolates. African Journal of Medical Science. 17: 133-140.

Pfau, A and Sacks, T (1981). The bacterial flora of the vaginal vestibule, urethra and vagina in premenopausal women with recurrent urinary tract infections. Journal of Urology. 126: 630-634.

Rapheal, S S; Hyde, T A; Mellor, L D; Spencer, F; Inwood, M J; Thompson, S; Byrant, N J (1983). Lynch's Medical Laboratory Technology. $4^{\text {th }}$ edition. pp. 434436. W.B. Saunders Company, Tokyo.

Senewiratne, B; Senewiratne, K; Hettiarachchi, J (1973). Bacteriology and antibiotic sensitivity in acute urinary tract infection in Ceylon. Lancet, I: 222-225.

Sleigh, J D and Timbury, M C (1986). Notes on Medical Bacteriology. $2^{\text {nd }}$ edition. pp. $212-218$. Churchill Livingstone Inc., 1560 Broadway, New York.

Stamey, T A and Pfau, A (1970). Urinary Infections: A selective review and some observations. California Medicine, 113:16-35.

Watanabe, T (1966). Infectious drug resistance in enteric bacteria. New England Journal of Medicine, 275: 888 $-894$.

Whalley, P J; Cunningham, F G; Martin, F.G (1975). Transient renal dysfunction associated with acute pyelonephritis of pregnancy. Obstetrics and $\begin{array}{lllll}\text { Gynecology, } & 46: & 174 & - & 177\end{array}$ 